\title{
Optimizing the Flow of Inpatient Acceptance at the Internal Medicine Clinic of Stone Baptist Hospital
}

\author{
Lidia Emilinda*, Dolly Irbantoro**, Tita Hariyanti*** \\ *M Author Correspondence: lidyaemilinda@gmail.com \\ *Universitas Brawijaya, Malang, East Java, Indonesia \\ **Universitas Brawijaya, Malang, East Java, Indonesia \\ ***Universitas Brawijaya, Malang, East Java, Indonesia

\begin{tabular}{l}
\hline I N D E X I N G \\
\hline Keywords: \\
Internal Medicine \\
Clinic; \\
Admissions For \\
Inpatients; \\
Waiting Time;
\end{tabular}

\begin{abstract}
A B S T R AC T
The waiting time for hospitalization in internal medicine clinics at Baptis Batu Hospital has not yet reached the minimum service standard indicator. Batu Baptis Hospital determines the standard inpatient waiting time $<120$ minutes starting from the patient being decided on hospitalization until the patient enters the care room and infusion installation by the nurse. Reducing the factors that affect the length of time waiting for hospitalization in internal medicine clinics. This study was qualitative with unstructured interviews, FGDs, and observations with 3 participants. Primary data were obtained from time motion study observations and secondary data were obtained from the minimum service standard report (SPM) of Baptis Hospital Batu. The main factor of the length of time waiting for inpatient in internal medicine clinics was the absence of special officers in the action room and the role of inter-unit officers did not communicate well to optimize inpatient waiting time. The flow process for inpatient admissions exceeds the standard causing a long waiting time for inpatients. Suggestion from this research is the addition of admission units in outpatient installations to reduce the waiting time.
\end{abstract}

Kata kunci:

Klinik Penyakit Dalam;

Penerimaan Asien

Rawat Inap;

Waktu Tunggu;
Waktu tunggu rawat inap di klinik penyakit dalam RS Baptis Batu masih belum mencapai indikator standar pelayanan minimum. RS Baptis Batu menentukan standar waktu tunggu rawat inap $<120$ menit dimulai dari pasien di putuskan rawat inap sampai pasien memasuki kamar perawatan serta pemasangan infus oleh perawat. Mengurangi faktor-faktor yang mempengaruhi lama waktu tunggu rawat inap di klinik penyakit dalam. Penelitian ini adalah kualitatif dengan wawancara tidak terstruktur, FGD, dan observasi dengan 3 orang partisipan. Data primer diperoleh dari hasil observasi time motion study dan data sekunder diperoleh dari laporan standar pelayanan minimal (SPM) rumah sakit Baptis Batu.. Faktor utama lama waktu tunggu rawat inap di klinik penyakit dalam adalah tidak adanya petugas khusus di ruang tindakan serta peran petugas antar unit kurang berkomunikasi dengan baik untuk mengoptimalkan waktu tunggu rawat inap. Proses alur penerimaan pasien rawat inap melebihi standar menyebabkan lama waktu tunggu rawat inap. Saran dari penelitian ini adalah penambahan unit admisi di instalasi rawat jalan untuk mengurangi lama waktu tunggu.

(C) 2019 JMMR. All rights reserved

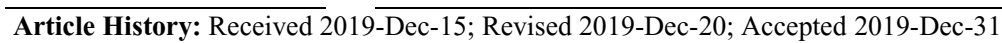

\section{INTRODUCTION}

Hospital services in the current era are inseparable from the economic development of the community. This is reflected in the changes in the classic function of the hospital which initially only provided curative services to patients through outpatient and inpatient shifts to more comprehensive services including primitive, preventive, curative and rehabilitative.1 Hospital is a health service institution that organizes a complete individual health service that provides inpatient, outpatient and emergency services while inpatient is a service for patients entering the hospital who need a place of care for care, diagnosis, care, medical care and or services other medical. ${ }^{2}$ Law no 36 on health and in chapter 1 article 11 describes health efforts, namely every activity and or series of activities carried out in an integrated, integrated and sustainable manner. Hospitals are capital intensive, business intensive, labor intensive and problem intensive organizations. Along with the growth of hospitals in Indonesia to be able to compete in the health industry, every hospital. competing to improve the quality or quality of service, of course improving the quality of this service must be carried out in all aspects of 
the hospital, this also applies to the Stone Baptist Hospital.3 In addition to improving the quality or quality of services also with health services with the establishment of Minimum Service Standards (SPM) hospitals. ${ }^{4}$

Determination of SPM with the stipulation of Minister of Health Decree number 129 / Menkes / SK / II / 2008 concerning Minimum Service Standards, hospitals have become a necessity in every health service available to guarantee the quality of service excellence as the end result of a quality of service provided. ${ }^{5}$ Each hospital service and management unit has been determined SPM as a reference Minimum Service Standards that must be obeyed. ${ }^{6}$ One indicator of outpatient SPM related to waiting time for inpatient care at outpatient installation $<120$ minutes. ${ }^{7}$

Waiting time is a problem in every agency, including health services. The first hospital door is in an outpatient facility where there are many patients who come to visit for treatment, rehabilitation and also the entrance of the possibility of patients being hospitalized. The long waiting time in the outpatient service process will hamper the service, which has an impact on the queues that accumulate and result in inefficient services. The waiting time for inpatient is starting from the patient's decision to stay in the patient until the patient enters the inpatient room. The patient's waiting time reflects how the health care facility manages the service components that are tailored to the patient's situation and expectations. ${ }^{8}$ Good acceptable service if it has good quality. One of the good quality of health services when related to services marked by patient waiting time. $^{9}$

The waiting time for inpatient is starting from the patient's decision to stay in the patient until the patient enters the inpatient room. The patient's waiting time reflects how the health care facility manages the service components that are tailored to the patient's situation and expectations. 8 In a study conducted by the National Association of Health Care Access Management (NAHAM), the average waiting time for admission inpatients (inpatient admission) was 7.7 minutes and the interview time averaged 10.57 minutes so the total amount of time was around 18 minutes 4 seconds. 3 In Pondok Indah Hospital, it was found that the average length of the patient registration process was in the hospital for about 32 minutes 7 seconds. This figure may vary from one institution to another depending on procedures, processes and the amount of data collected by the administration, these figures can serve as a comparison because there is no standardization of patient admission time in the inpatient unit established by the Indonesian Ministry of Health. ${ }^{10}$
The inpatient unit of Batu Baptis Hospital has 107 TT with the number of patients in the inpatient unit fluctuating and shows an increase from year to year (2015, 6,259 patients), 2016 (7,823 patients), 2017 (7,899 patients), and 2018 (8,599 patients). Initial admission of inpatients to Baptist Batu Hospital (preadmission) through 2 doors, namely from outpatient (IRJ) and emergency department (IGD) installations. ${ }^{11}$

Based on the data obtained in the percentage of inpatient visits from IRJ has decreased. Inpatient visits from IRJ $3 \%$ of the total patients who visited IRJ while for emergency patients it is likely that almost all of them will certainly be hospitalized. ${ }^{12}$

Based on observations of patients hospitalized from internal medicine clinics often found long and long queues. Basically, outpatients are patients who are not ready to be hospitalized so that the long waiting time will potentially lead to patient complaints and also have a direct impact on the quality of service and a decrease in inpatient visits. The waiting time for inpatients in internal medicine clinics is more than the indicator set by the Stone Baptist Hospital ( $<120$ Minutes). So the authors are interested in examining the causative factors as well as providing solutions to the hospital and the results of observations can optimize the waiting time for inpatient admissions at the disease clinic in Stone Baptist Hospital.

\section{RESEARCH METHOD}

This study uses a qualitative approach beginning with unstructured interviews with related units and observation with flow analysis of the inpatient process at internal medicine clinics. ${ }^{13}$ Observations were made at the clinical disease clinical hour on Monday to Saturday at 8:00 to the end. To get an idea of the causal factors that affect the length of waiting time an analysis of the causes of the problem is done using the Ishikawa Diagram (Fishbone) method which is viewed from four perspectives: Man, Material, Methods, Mechine. The diagram is to help visually display the sources of the cause of the problem so that it makes it easy to identify the root cause of the problem. ${ }^{14}$

Data processing and analysis starts from making the cross functional flowchart (process flow) of the units involved, observing the time and distance needed to complete the process in each unit. The time calculation is done starting from the doctor of internal medicine polyclinic to declare the patient to be treated until the patient lies in the inpatient room and do the initial observation with infusion installation by the nurse. 
Measurement of quality and patient safety at Batu Baptist Hospital uses the Minimum Service Standards (SPM) and Hospital Level Indicators. There are still some indicators of quality and safety of Batu Baptist Hospital patients that still do not meet the standards. Of all the indicators of the Stone Baptist Hospital quality there is an interesting indicator that is the waiting time of patients at the time of admission both from the emergency room door and outpatient still has not reached the standard. In general, the length of time before the patient is sent to the inpatient room takes about 1 hour, to prepare the readiness of the inpatient room. This is usually the case for most patients, because they have to wait a while later. In the case of patients sometimes have to endure the pain and want to immediately rest and immediately get treatment from medical personnel in the inpatient room. ${ }^{15}$

Batu Baptist Hospital has an outpatient clinic with 15 rooms including 3 internal medicine rooms used for morning \& evening practice by specialists, the latest information is there is an additional one for specialists in internal medicine so that in total there are 3 specialists in internal medicine. Outpatient clinic also has 2 treatment rooms in each treatment room has 2 TT. Internal clinic patients visit a lot compared to other clinics, also have the opportunity for inpatients from internal medicine clinics. For the morning service number of outpatient assistants who guard 10 people including 1 for administration, 1 for circuits (delivering files, status distribution in outpatient clinics, helping deliver patients to hospitalization) 3 nurses are needed 1 for assistant doctors at internal medicine rooms, 3 for other clinical assistants such as (obstetric clinics, clinics, nerves, clinics, surgeries, pediatric clinics) and 2 who are on guard at nurstasion. To schedule a specialist in internal medicine alone, there are 2 doctors who practice at 08.00 to finish, so they need room 3 because one of the doctors keeps 2 rooms.

Based on preliminary survey results that there are fewer inpatients who are hospitalized through outpatient installations compared to inpatients who enter through the emergency room. Table 1 comparison of inpatient visits at IRJ and ED ward at Babptis Stone Hospital.

Table 1. comparison of inpatient visits in IRJ and IGD installations

\begin{tabular}{|c|c|c|c|c|c|}
\hline Number & Information & 2018 & $2018(\%)$ & 2017 & $2017(\%)$ \\
\hline \multirow[t]{2}{*}{1.} & Patient RJ & 87.488 & & 64.683 & \\
\hline & Patient treated & 1.984 & $2,3 \%$ & 2.002 & $3 \%$ \\
\hline \multirow[t]{3}{*}{2.} & Patient IGD & 4.563 & & 4.016 & \\
\hline & \multirow{2}{*}{ Patient treated } & & $88,5 \%$ & & $96,7 \%$ \\
\hline & & 4.036 & & 3.883 & \\
\hline
\end{tabular}

Based on the table above shows that the percentage of inpatient visits from IRJ has decreased. Inpatient visits from IRJ $3 \%$ of the total patients who visited IRJ while for emergency patients it is likely that almost all of them will certainly be hospitalized. This is also in line with the results of observations on 21 August - 6 September 2019, there were 7 people who needed waiting time at the internal medicine clinic for more than $>60$ minutes and waiting time for hospitalization $>120$ minutes. ${ }^{12}$

Observation results of the long waiting time of outpatients from patients registering until the patient gets a doctor's examination takes 230 minutes, as well as the length of time waiting for inpatients to get 3 patients observation results starting from the patient decided on inpatient until entering the inpatient room, and from one of the patients it takes 240 minutes.

Table 2. waiting time in outpatient installations

\begin{tabular}{llll}
\hline Number & \multicolumn{1}{c}{ Information } & \multicolumn{1}{c}{$\begin{array}{c}\text { Time } \\
\text { (minute) }\end{array}$} & Total \\
\hline 1. & $\begin{array}{l}\text { waiting on the } 230 \\
\text { doctor's call } \\
\text { When entering the } 240\end{array}$ & 470 Minute \\
& inpatient room & & \\
\hline
\end{tabular}

Based on observations of patients hospitalized from internal medicine clinics often found long and long queues. The factors that affect the waiting time for hospitalization are: 
1. The time of inpatient registration at the internal medicine clinic exceeds the standard set by the hospital ( $<120$ minutes).

2. Completeness of inpatient status file, for example: initial medical assessment and early nursing assessment is incomplete.

3. Lack of nurses in the outpatient installation action room (IRJ).

4. It is not clear the doctor's advice in writing a prescription on the inpatient resume so as making the clerk reconfirmation.

5. Awaiting confirmation of ECG results and further advice from DPJP doctors who are sometimes difficult to contact.

This has the potential to reduce hospitalization patients, the potential for patient complaints and reduce patient satisfaction. One of the problems that should get special attention from Batu Baptis Hospital is to reduce patient waiting time from outpatient to inpatient. ${ }^{16}$ The flow of the admission process for inpatients must be done quickly because the delay will increase morbidity and mortality as well as the psychological of the patient and family. ${ }^{17}$ Basically, outpatients are patients who are not ready for inpatient care so that the long waiting time will have an impact on patient satisfaction which has an indirect impact on the reduction of inpatient visits at outpatient installations (IRJ). ${ }^{18}$

After doing a time motion study flow of admissions for inpatients in internal medicine clinics, it is known that the biggest factor occurs in the outpatient department. Based on observations, documentation and indepth interviews with respondents, it can be identified the cause of the problem which is divided into 4 elements of management (man, money, material, method). ${ }^{19}$

The root search for the problem was carried out through interviews with the Deputy Director of Services, the head of the outpatient installation, the inpatient and nursing manager, the registrar, the head of the data and information center. By interviewing separately with each respondent, 10 (ten) points were identified as the cause of the problem.

Determining the root cause of the ten things identified as a problem above, scoring was done using the method USG (urgency, seriousness and growth).$^{20}$ Each respondent was again asked to give a score by first getting an explanation on how to score. The scoring uses the Likert scale, which is a scale of $1-5$. Based on the results of the scoring obtained the three highest problems. The first highest problem is that there are no special admissions inpatients in the RJ clinic, the second patient waits in the action room to get a room that is suitable and the third is there are rooms available in the inpatient but the officer does not leave because the room does not match the guarantee. Of the three root problems that have been obtained, made 5 "why" to determine the root of the problem before analysis using CARL for the choice of solutions offered.

\section{CONCLUSION}

The length of time waiting for hospitalization at the internal medicine clinic at Baptis Batu Hospital is not in accordance with the standards set by the Hospital. As for several factors, the length of time waiting for inpatients in internal medicine is that there is no place for admission registration in outpatient installations which is the root of the problem of waiting time for inpatients in internal medicine clinics.

\section{ACKNOWLEDGMENT}

Thank you to the director of the Stone Baptist hospital who allowed me to do an internship for 2 months. Thanks to Dr. Tita who has guided me so that I can publish a journal about hospital management.

\section{REFERENCE}

1. UUD RI 36 tentang kesehatan. Undang-Undang Republik Indonesia Nomor 36 Tahun 2009 Tentang Kesehatan. Diakses dari bpkp go id pada tanggal. 2013;12.

2. Permana A. Fungsi Sosial Rumah Sakit Berdasarkan Ketentuan Pasal 29 Ayat 1 Huruf F Undang Undang No 44 Tahun 2009 Tentang Rumah Sakit Dikaitkan Dengan Undang Undang No 36 Tahun 2009 Tentang Kesehatan. Fakultas Hukum (UNISBA); 2016.

3. Dewi PK. Analisis Alur Proses Penerimaan Pasien Rawat Inap di Rumah Sakit “ X " Tahun 2015 dengan Pendekatan Lean Hospital. 2015;2:1-16.

4. Dep Kes RI. Keputusan Menteri Kesehatan Republik Indonesia Nomor: 129/Menkes/Sk/Ii/2008 Tentang Standar Pelayanan Minimal Rumah Sakit. Nomor Tambah Lembaran Negara Nomor 4355 Nomor Tambah Lembaran Negara Nomor. 2008;4400(1):5.

5. Hariyanti T, L EW. Hubungan Keterlambatan Kedatangan Dokter terhadap Kepuasan Pasien di Instalasi Rawat Jalan Doctors ' Delays on Arrival to Patient Satisfaction Relationship in Outpatient Units. 2014;28(1):31-5.

6. Indonesia R. Keputusan Menteri Kesehatan No. 129/MENKES/SK/II/2008 tentang Standar Pelayanan Minimal Rumah Sakit; 2004.

7. SPM RSBB. Rekap SPM RSBB 2019 (23 Jul 2019).

8. Anggita DS. Analisis Waktu Tunggu Pemberian Informasi Tagihan asien Pulang Rawat Inap di RS Grha Permata Ibu 
Tahun 2012. Univ Indones. 2012;

9. Bustani NM, Rattu AJ, Saerang JSM. Analisis Lama Waktu Tunggu Pelayanan Pasien Rawat Jalan Di Balai Kesehatan Mata Masyarakat Propinsi Sulawesi Utara. J e-Biomedik. 2015;3(3).

10. Suryanti N. Faktor-faktor yang berhubungan dengan lamanya waktu proses pendaftaran pasien rawat inap di rumah sakit pondok indah (tahun 2002). FKM-UI; 2002.

11. RS BB. Laporan Bulanan IRJ RSBB 2019. 2019.

12. RS BB. Laporan Kegiatan Pelayanan Medik Th. 2018. 2018;(0341).

13. Patilima H. Metode penelitian kualitatif. 2005;

14. Asmoko H. Teknik Ilustrasi Masalah-Fishbone Diagrams. Magelang Badan Pendidik Dan Pelatih Keuang Dep Keuang. 2013;

15. Haryanto AT, Suranto J. Pelayanan Kesehatan (Studi Rawat Inap Di Pusat Kesehatan Masyarakat (Puskesmas), Kecamatan Baturetno Kabupaten Wonogiri). 2012;

16. Hariyanti T, Susilo S. Pengembangan Alur Pasien dan Berkas Rekam Medis sebagai Optimalisasi Sistem Informasi Rekam Medis. J Kedokt Brawijaya. 2015;28(2):129-35.

17. Fuanasari AD, Suparwati A, Wigati PA. Analisis Alur Pelayanan Dan Antrian Di Loket Pendaftaran Pasien Rawat Jalan. J Kesehat Masy. 2014;2(1):15-21.

18. Laeliyah N, Subekti H. Waktu tunggu pelayanan rawat jalan dengan kepuasan pasien terhadap pelayanan di Rawat Jalan RSUD Kabupaten Indramayu. J Kesehat Vokasional. 2017;1(2):102-12.

19. Wardani R. He Analysis Of Interest To Treatment Outpatients Back Based On Management Resource Approach (Man, Money, Material, Machine, Method/5m). In: Proceeding Surabaya International Health Conference. 2017.

20. Purwanto H, Indiati I, Hidayat T. Faktor Penyebab Waktu Tunggu Lama di Pelayanan Instalasi Farmasi Rawat Jalan RSUD Blambangan. J Kedokt Brawijaya. 2015;28(2):15962 . 